\title{
KONVERSI KORAL LAUT MENJADI HIDROKSIAPATIT DENGAN METODE SONIKASI
}

\author{
Yessy Warastuti, Basril Abbas, dan Nani Suryani \\ Pusat Aplikasi Isotop dan Radiasi (PAIR) - Badan Tenaga Nuklir Nasional \\ Jl.Lebak Bulus Raya N0.49, Jakarta 12440 \\ E-mail : warastuti79@gmail.com
}

Received: 7 Juni 2017; revised: 11 Juni 2017; accepted: 13 September 2017

\begin{abstract}
ABSTRAK
KONVERSI KORAL LAUT MENJADI HIDROKSIAPATIT DENGAN METODE SONIKASI. Sintesis coralline hydroxyapatite $(C H A p)$ dari koral laut yang umumnya menggunakan metode basah yaitu hidrotermal yang memerlukan suhu dan tekanan tinggi. Tujuan dari penelitian ini adalah mengkonversi koral laut Goniopora sp. menjadi CHAp dengan metode sonikasi pada suhu rendah. Goniopora sp. dikalsinasi pada suhu $900{ }^{\circ} \mathrm{C}$ selama 3 jam, kemudian direaksikan dengan diammonium hidrogen fosfat $\left[\left(\mathrm{NH}_{4}\right)_{2} \mathrm{HPO}_{4}\right]$ dan mono kalium fosfat $\left(\mathrm{KH}_{2} \mathrm{PO}_{4}\right)$ dengan waktu sonikasi 6 jam sampai 24 jam pada suhu $60^{\circ} \mathrm{C}$. Hasil penelitian menunjukkan bahwa telah terjadi perubahan fase dari koral menjadi $C H A p$ yang dapat dilihat dari identifikasi pola difraksi sinar-X khas dari hidroksiapatit dengan derajat kristalinitas sebesar 66\% untuk CHAp dengan waktu sonikasi 24 jam. Spektrum Fourier Transform Infra Red Spectroscopy (FTIR) menunjukkan puncak serapan khas dari hidroksiapatit yaitu gugus $\mathrm{OH}$ pada $3637 \mathrm{~cm}^{-1}$ sampai dengan $3404 \mathrm{~cm}^{-1}$ fosfat $\left(\mathrm{PO}_{4}^{3-}\right)$ pada $569 \mathrm{~cm}^{-1}, 603 \mathrm{~cm}^{-1}$, $960 \mathrm{~cm}^{-1}$, dan $1045 \mathrm{~cm}^{-1}$ serta karbonat $\left(\mathrm{CO}_{3}{ }^{2-}\right)$ pada $1456 \mathrm{~cm}^{-1}$ dan $873 \mathrm{~cm}^{-1}$. Carbonated hydroxyapatite yang terbentuk adalah tipe-B. Rasio $\mathrm{Ca} / \mathrm{P}$ yang dihasilkan untuk $\mathrm{CH} A \mathrm{p}$ dengan waktu sonikasi 24 jam adalah 1,7.
\end{abstract}

Kata kunci : Koral, Goniopora, Hidroksiapatit, Coralline hydroxyapatite, Sonikasi

\section{ABSTRACT}

CONVERSION OF SEA CORAL INTO HYDROXYAPATITE WITH SONICATION METHOD. Synthesis of coralline hydroxyapatite (CHAp) of sea coral generally used the wet method, hydrothermal requiring high temperatures and pressures. The purpose of this study was to convert sea coral Goniopora sp. become CHAp with sonication methods at low temperatures. Goniopora sp. calcined at $900{ }^{\circ} \mathrm{C}$ for 3 hours, then reacted with hydrogen diammonium phosphate $\left[\left(\mathrm{NH}_{4}\right)_{2} \mathrm{HPO}_{4}\right]$ and monopotassium phosphate $\left(\mathrm{KH}_{2} \mathrm{PO}_{4}\right)$ with sonication time of 6 hours to 24 hours at a temperature of $60^{\circ} \mathrm{C}$. The results showed that there had been a change in the phase of coral into a CHAp that can be seen from the identification of the X-ray diffraction pattern characteristic of hydroxyapatite with the degree of crystallinity of $66 \%$ for the CHAp with the sonication time of 24 hours. Spectra Fourier Transform Infra Red Spectroscopy (FTIR) showed typical absorption peak of hydroxyapatite which is an $\mathrm{OH}$ group at $3637 \mathrm{~cm}^{-1}$ to $3404 \mathrm{~cm}^{-1}$ phosphate $\left(\mathrm{PO}_{4}{ }^{3-}\right)$ at $569 \mathrm{~cm}^{-1}, 603 \mathrm{~cm}^{-1}, 960 \mathrm{~cm}^{-1}$, and $1045 \mathrm{~cm}^{-1}$ and carbonate $\left(\mathrm{CO}_{3}{ }^{2-}\right)$ at $1456 \mathrm{~cm}^{-1}$ and $873 \mathrm{~cm}^{-1}$. Carbonated hydroxyapatite formed is type- $B$. The ratio of $\mathrm{Ca} / P$ produced to the CHAp with the sonication time of 24 hours is 1.7 .

Key words : Coral, Goniopora, Hydroxyapatite, Coralline hydroxyapatite, Sonication

\section{PENDAHULUAN}

Material yang banyak diperlukan untuk memperbaiki dan meregenerasi tulang adalah senyawa dari garam kalsium fosfat seperti hidroksiapatit. Hidroksiapatit, $\mathrm{Ca}_{10}\left(\mathrm{PO}_{4}\right)_{6}(\mathrm{OH})_{2}$ adalah mineral utama penyusun tulang dan gigi. Material pengganti tulang yang tersusun atas hidroksiapatit, telah digunakan secara luas untuk aplikasi biomedis seperti di bidang periodontologi dan ortopedi. Hidroksiapatit digunakan karena memiliki sifat biokompatibilitas, bioaktivitas, osteokonduktif, non toksik dan non imunogenik (Silva et al. 2012).
Hidroksiapatit dapat disintesis menggunakan bahan sintetis dan dapat pula diekstraksi dari bahan biologi seperti tulang sapi, sisik ikan, cangkang telur, maupun sumber dari hewan laut atau disebut juga sumber biogenik. Biogenik antara lain bersumber dari koral, sponges, moluska, dan tulang ikan. Sumber biogenik merupakan pilihan yang baik untuk menyintesis biomaterial karena menyerupai jaringan keras pada manusia.

Koral laut berasal dari family poratidae memiliki beberapa spesies, diantaranya Porites, 
Goniopora, Corallina officinalis, Acropora, dan lain-lain tersusun atas rangka kalsium karbonat $\left(\mathrm{CaCO}_{3}\right)$. Goniopora paling banyak diteliti karena memiliki kesamaan mikroskopis dengan tulang kanselus. Data dari Global Marine Aquarium Database (GMAD) menunjukkan bahwa Indonesia, Fiji, Kepulauan Solomon, dan Tonga memasok lebih dari 95\% ekspor koral dan sebesar $71 \%$ diekspor oleh Indonesia. Goniopora adalah jenis yang paling banyak diekspor setelah Scleractinia (Wabnitz et al. 2003). Gabungan antara rangka $\mathrm{CaCO}_{3}$ dan interkonektivitas antar pori, menjadikan koral potensial sebagai bahan pengganti tulang (Clarke et al. 2011). Penelitian sebelumnya menyebutkan bahwa koral kurang sesuai untuk beberapa aplikasi biomedis karena tingkat disolusinya lebih cepat dan memiliki kestabilan struktur yang lemah sehingga menimbulkan reaksi inflamasi ketika dijadikan implan (Silva et al. 2012; Correlo et al. 2011; Yoo, Park, and Lee 2015). Untuk mengatasi keterbatasan tersebut, perlu dilakukan konversi rangka kalsium karbonat pada koral laut menjadi struktur yang lebih stabil yaitu kalsium fosfat sebagai penyusun coralline hydroxyapatite (CHAp).

CHAp cukup efektif dan aman secara klinis jika digunakan sebagai implan substitusi dengan tingkat resorpsi yang lebih lambat (Dinopoulos, Dimitriou, and Giannoudis 2012). Metode konversi koral menjadi CHAp yang umum digunakan adalah metode hidrotermal. (Sivakumar et al. 1996) melakukan sintesis hidroksiapatit dari Goniopora yang berasal dari Teluk Mannar di perairan India Selatan. Koral dikalsinasi pada suhu $900{ }^{\circ} \mathrm{C}$ selama 2 jam kemudian dikarakterisasi $X R D, F T I R$, dan analisis termal. Hasilnya menunjukkan bahwa koral mengalami perubahan fase menjadi $\mathrm{CHAp}$.

Proses hidrotermal termasuk metode basah yang identik dengan reaksi senyawa kimia dalam larutan berair pada suhu tinggi. Suhu yang digunakan berkisar antara $180^{\circ} \mathrm{C}$ sampai dengan $250^{\circ} \mathrm{C}$ (Xu et al. 2001; Akram et al. 2014). Metode basah seperti hidrotermal memiliki kelemahan yaitu memerlukan peralatan yang lebih mahal karena dilakukan pada suhu dan tekanan tinggi. Selain itu, kristalinitas dan kemurnian fase dari partikel yang dihasilkan sulit terkontrol (Sadat-Shojai et al. 2013). Untuk mengatasi kekurangan tersebut perlu dilakukan metode lain sebagai alternatif metode konversi koral menjadi CHAp.

Metode konversi rangka $\mathrm{CaCO}_{3}$ menjadi CHAp pada penelitian ini menggunakan metode sonikasi. Sonikasi menyebabkan peronggaan, dimana terbentuk gelembung udara dalam media air yang dapat merangsang reaktivitas spesies kimia yang terlibat sehingga terjadi reaksi percepatan heterogen antara reaktan padat dan cair secara efektif. Sonikasi merupakan cara yang efektif untuk menghancurkan partikel menjadi bentuk yang lebih kecil (Hazar Yoruç and Ipek 2012). Metode sonikasi memiliki kelebihan jika dibandingkan dengan metode lain yaitu tidak memerlukan suhu tinggi dan stabilizer pada prosesnya sehingga relatif lebih murah, cepat, dan dapat diaplikasikan pada skala besar. Hal tersebut dapat dilihat dari penelitian sebelumnya yang dilakukan oleh (Gopi et al. 2012) yang melakukan sintesis hidroksiapatit nanokomposit menggunakan ultrasonik pada frekuensi 28/35 $\mathrm{kHz}-150 / 320$ W. Melalui metode sonikasi dihasilkan hidroksiapatit yang homogen dan terdifusi dengan baik.

Penelitian ini bertujuan untuk mengkonversi koral laut menjadi hidroksiapatit dengan metode sonikasi. Koral dari genus Goniopora sp. direaksikan dengan diammonium hidrogen fosfat $\left[\left(\mathrm{NH}_{4}\right)_{2} \mathrm{HPO}_{4}\right]$ dan mono kalium fosfat $\left(\mathrm{KH}_{2} \mathrm{PO}_{4}\right)$. Hasil penelitian ini diharapkan dapat memberikan informasi mengenai karakterisasi yang dihasilkan dari konversi koral laut menjadi CHAp dengan metode sonikasi.

\section{BAHAN DAN METODE}

\section{Bahan}

Pada penelitian ini, digunakan koral laut yaitu jenis Goniopora sp. dari family poratidae yang diperoleh dari Pusat Penelitian Oseanografi, LIPI. Bahan kimia yang digunakan antara lain diammonium hidrogen fosfat $\left[\left(\mathrm{NH}_{4}\right)_{2} \mathrm{HPO}_{4}\right]$, mono kalium fosfat $\left(\mathrm{KH}_{2} \mathrm{PO}_{4}\right)$, etanol, ammonium molibdat, ammonium vanadat, dan asam klorida dari Merck. Sedangkan alat yang digunakan dalam penelitian ini adalah spektrofotometer Fourier Transform Infra Red Spectrophotometer (FTIR) Prestige 21 model 8400 S, Diffractometer (XRD) XD-610, UV-Vis Spectrophotometer UV mini1240, Scanning Electron Microscope (SEM) JEOL, JSM-6390, dan Bransonic-3510 Ultrasonic $230 \mathrm{~V} / 355 \mathrm{~W}-50 / 60 \mathrm{kHz}$.

\section{Metode}

Penelitian ini dilakukan di laboratorium kimia PAIR-BATAN. Koral laut Goniopora sp. dicuci menggunakan air hangat dan cairan pembersih kemudian dikeringkan di dalam oven. Setelah kering, koral dikalsinasi dengan tanur pada suhu $900{ }^{\circ} \mathrm{C}$ selama tiga jam, lalu dihaluskan menjadi serbuk dengan menggunakan mortar. Serbuk koral kemudian dicuci melalui perendaman dengan etanol, lalu dikeringkan.

Konversi Goniopora sp. menjadi CHAp dilakukan dengan metode sonikasi seperti yang dikerjakan oleh (Rouhani, Taghavinia, and Rouhani 2010). Sonikasi dilakukan pada suhu yang lebih tinggi untuk memperoleh hidroksiapatit dengan kristalinitas yang lebih tinggi. Serbuk Goniopora tanur direaksikan 
dengan diammonium hidrogen fosfat dan mono kalium fosfat dengan perbandingan 3:2:1 dalam alat ultrasonik Bransonic-3510 Ultrasonic 230 V/355 W - 50/60 kHz. Campuran tersebut disonikasi dengan variasi waktu 6 jam sampai 24 jam pada suhu $60{ }^{\circ} \mathrm{C}$. Gambar 1 memperlihatkan diagram skema alat ultrasonik seperti yang telah dikerjakan oleh (Han et al. 2007).

Karakterisasi sifat fisik CHAp yang dilakukan antara lain analisis gugus fungsi dengan FTIR, analisis kristalinitas dengan $X R D$, analisis kadar kalsium dengan metode titrimetri, analisis kadar fosfor dengan metode MolibdatVanadat menggunakan spektrofotometri UV-Vis, serta analisis morfologi bahan dengan SEM-EDX.

\section{HASIL DAN PEMBAHASAN}

Konversi koral laut menjadi hidroksiapatit menghasilkan coralline hydroxyapatite (CHAp) dengan persamaan reaksi sebagai berikut (Silva et al. 2012; Correlo et al. 2011; Clara Piccirillo, Manuela M. Pintado 2013) :

$$
\begin{aligned}
& 10 \mathrm{CaCO}_{3}+6\left(\mathrm{NH}_{4}\right)_{2} \mathrm{HPO}_{4}+2 \mathrm{H}_{2} \mathrm{O} \rightarrow \\
& \mathrm{Ca}_{10}\left(\mathrm{PO}_{4}\right)_{6}(\mathrm{OH})_{2}+6\left(\mathrm{NH}_{4}\right)_{2} \mathrm{CO}_{3}+4 \mathrm{H}_{2} \mathrm{CO}_{3}
\end{aligned}
$$

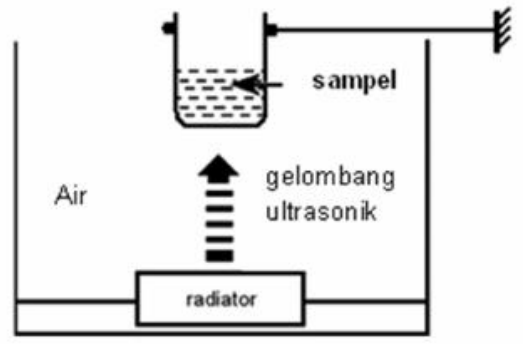

Gambar 1. Diagram skema alat ultrasonik

Larutan $\mathrm{KH}_{2} \mathrm{PO}_{4}$ yang ditambahkan berperan sebagai mineralizer untuk mempercepat proses konversi koral menjadi CHAp dan mencegah terbentuknya fase intermediate. Aragonit yang merupakan unsur utama penyusun koral, dapat langsung berubah menjadi hidroksiapatit, tanpa melalui fase intermediate menjadi kalsit ( $\mathrm{Xu}$ et al. 2001).

\section{Karakterisasi Coralline Hydroxyapatite dengan Fourier Transform Infra Red Spectrophotometer (FTIR)}

Spektrum FTIR dari koral Goniopora sp., Goniopora tanur, dan CHAp disajikan pada Gambar 2. Koral laut tersusun dari senyawa kalsium karbonat dengan mineral penyusun utama adalah aragonit. Hal tersebut dapat dilihat dari spektrum koral Goniopora sp. yang terbentuk. Puncak serapan vibrasi regang $\mathrm{OH}$

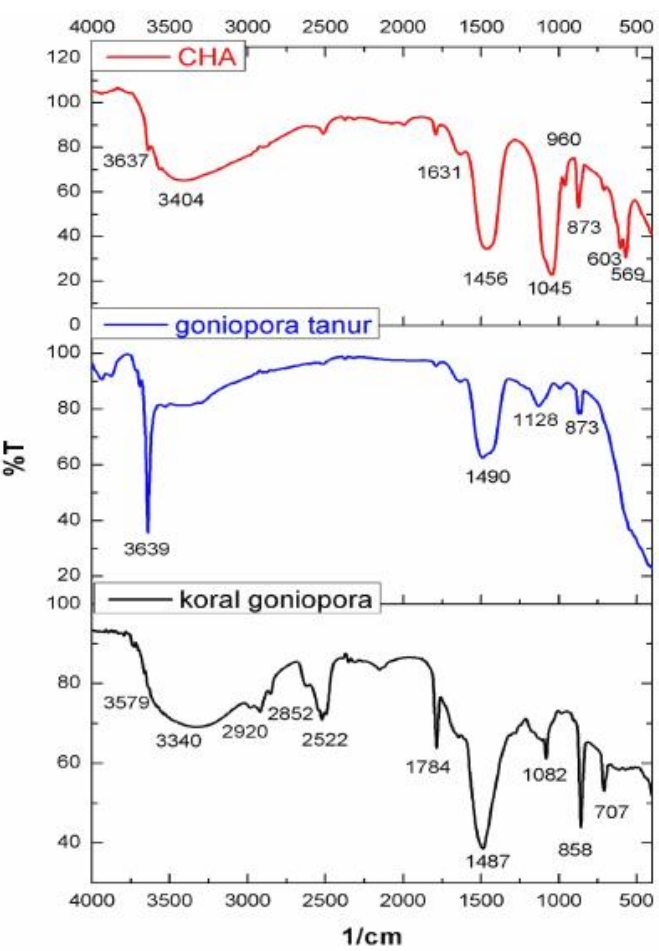

Gambar 2. Spektrum FTIR koral Goniopora, Goniopora tanur, dan CHAp

terlihat di daerah panjang gelombang $3340 \mathrm{~cm}^{-1}$ sampai dengan $3579 \mathrm{~cm}^{-1}$ dan vibrasi regang $\mathrm{C}-\mathrm{H}$ pada daerah $2852 \mathrm{~cm}^{-1}$ sampai dengan $2920 \mathrm{~cm}^{-1}$.

Selain itu terdapat pula vibrasi regang $\mathrm{OH}$ dan $\mathrm{C}=\mathrm{O}$ dari senyawa karboksilat di daerah $2522 \mathrm{~cm}^{-1}$ dan $1784 \mathrm{~cm}^{-1}$. Puncak serapan pada $707 \mathrm{~cm}^{-1}, 858 \mathrm{~cm}^{-1}, 1082 \mathrm{~cm}^{-1}$, dan $1487 \mathrm{~cm}^{-1}$ merupakan vibrasi karbonat $\left(\mathrm{CO}_{3}{ }^{2-}\right)$ yang khas dari unsur aragonit. Hasil tersebut sejalan dengan penelitian yang dilakukan oleh (Singh et al. 2016). Setelah dilakukan proses kalsinasi pada suhu $900^{\circ} \mathrm{C}$, puncak serapan vibrasi dari $\mathrm{C}-\mathrm{H}$, vibrasi $\mathrm{OH}$ dan $\mathrm{C}=\mathrm{O}$ dari senyawa karboksilat pada daerah $2900 \mathrm{~cm}^{-1}$ sampai dengan $1700 \mathrm{~cm}^{-1}$ yang semula terdapat pada koral sebelum tanur, menghilang setelah koral ditanur pada suhu tinggi. Hal tersebut mengindikasikan bahwa kandungan unsur organik yang ada pada koral, hilang karena pemanasan.

Puncak serapan dengan intensitas tajam pada $3639 \mathrm{~cm}^{-1}$ menunjukkan gugus fungsi $\mathrm{OH}$ terikat $(\mathrm{OH}$ pada struktur koral) yang tidak hilang karena pemanasan. Setelah koral direaksikan dengan larutan diammonium hidrogen fosfat $\left[\left(\mathrm{NH}_{4}\right)_{2} \mathrm{HPO}_{4}\right]$ dan mono kalium fosfat $\left(\mathrm{KH}_{2} \mathrm{PO}_{4}\right)$ dengan metode sonikasi, terjadi konversi Goniopora menjadi CHAp. Hal tersebut dapat terlihat dari munculnya pita serapan khas dari hidroksiapatit pada panjang gelombang $3637 \mathrm{~cm}^{-1}$ sampai dengan $3404 \mathrm{~cm}^{-1}$ yang 
merupakan vibrasi regang $\mathrm{OH}$, dan vibrasi tekuk $\mathrm{H}-\mathrm{OH}$ pada $1631 \mathrm{~cm}^{-1}$. Vibrasi deformasi fosfat $\left(\mathrm{PO}_{4}{ }^{3-}\right.$ ) pada daerah $569 \mathrm{~cm}^{-1}$ dan $603 \mathrm{~cm}^{-1}$ serta vibrasi regang fosfat pada $960 \mathrm{~cm}^{-1}$ dan $1045 \mathrm{~cm}^{-1}$.

Selain itu, terdapat puncak serapan tajam pada daerah $1456 \mathrm{~cm}^{-1}$ dan $873 \mathrm{~cm}^{-1}$ yang menunjukkan vibrasi regang dan tekuk $\mathrm{C}-\mathrm{O}$ dari unsur karbonat $\left(\mathrm{CO}_{3}{ }^{2-}\right)$. Spektrum $\mathrm{CHAp}$ yang dihasilkan memiliki kesamaan dengan CHAp yang diteliti oleh (Sivakumar et al. 1996). Pita serapan karbonat yang spesifik pada panjang gelombang $873 \mathrm{~cm}^{-1}$ adalah vibrasi bending/tekuk C-O $\left(v_{2}\right)$ dan vibrasi regang asimetris C-O $\left(v_{3}\right)$ pada $1456 \mathrm{~cm}^{-1}$ menunjukkan bahwa karbonat yang terbentuk adalah tipe-B, dimana karbonat, $\mathrm{CO}_{3}{ }^{2-}$ mensubtitusi fosfat $\left(\mathrm{PO}_{4}{ }^{3-}\right)$ (Ren and Leng 2011). Jika dibandingkan dengan hidroksiapatit yang terbentuk secara stoikiometri, hidroksiapatit dengan unsur karbonat didalamnya menunjukkan sifat osteokonduktivitas dan bioresorbabilitas yang lebih baik, karena lebih mirip dengan komposisi dalam mineral tulang (Kee, Ismail, and Mohd Noor 2013).

Waktu sonikasi yang dilakukan juga berpengaruh terhadap spektrum FTIR yang dihasilkan. Gambar 3 menunjukkan spektrum FTIR dari CHAp dengan waktu sonikasi 6 jam sampai dengan 24 jam. Terlihat bahwa pita serapan $\mathrm{OH}$ di daerah $3637 \mathrm{~cm}^{-1}$ yang pada CHAp hasil sonikasi 6 jam terlihat lebih tajam intensitasnya, tetapi seiring dengan bertambahnya waktu sonikasi menjadi semakin kecil. Begitu pula halnya dengan pita serapan karbonat di daerah $873 \mathrm{~cm}^{-1}$, menunjukkan intensitas yang semakin berkurang seiring dengan bertambahnya waktu sonikasi. Hal tersebut menunjukkan bahwa semakin lama waktu sonikasi, proses konversi Goniopora menjadi CHAp semakin sempurna, yang ditandai dengan adanya perubahan unsur karbonat sebagai penyusun koral berubah atau mensubtitusi $\mathrm{OH}$ dan fosfat (Ren and Leng 2011).

Hasil spektrum FTIR dapat dikorelasikan dengan hasil pola difraksi sinar- $X$ yang terbentuk. Proses pencucian Goniopora tanur dengan etanol juga berpengaruh terhadap spektrum FTIR CHAp yang dihasilkan (Gambar 4).

Gambar 4 menunjukkan spektrum FTIR CHAp yang diproses dari goniopora tanur yang sebelumnya dicuci dengan etanol. Koral yang memiliki struktur berpori, tersusun atas 97\% mineral (utamanya $\mathrm{CaCO}_{3}$ ) dan $3 \%$ oksida besi magnesium yang tergabung dalam substansi organik. Substansi organik, utamanya terdiri dari protein. Pencucian dengan menggunakan etanol bertujuan untuk membersihkan koral dari substansi organik tersebut (Christopher et al. 2012).

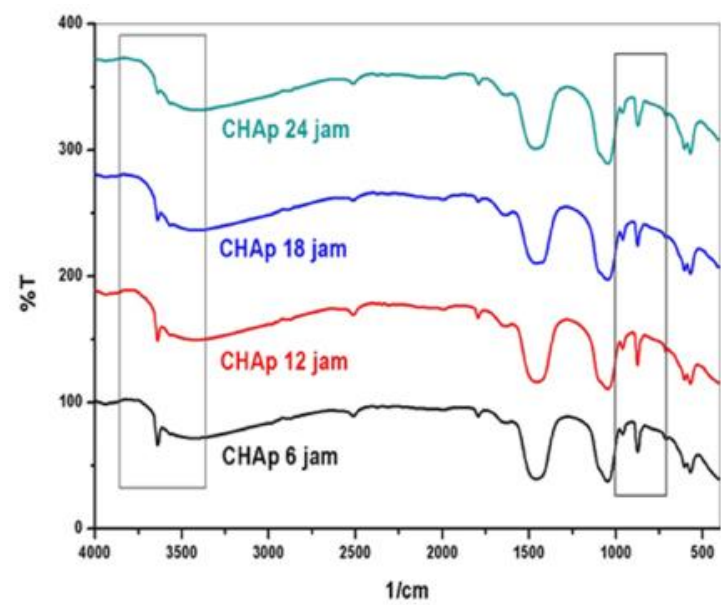

Gambar 3. Spektrum FTIR CHAp dengan waktu sonikasi 6 jam sampai dengan 24 jam

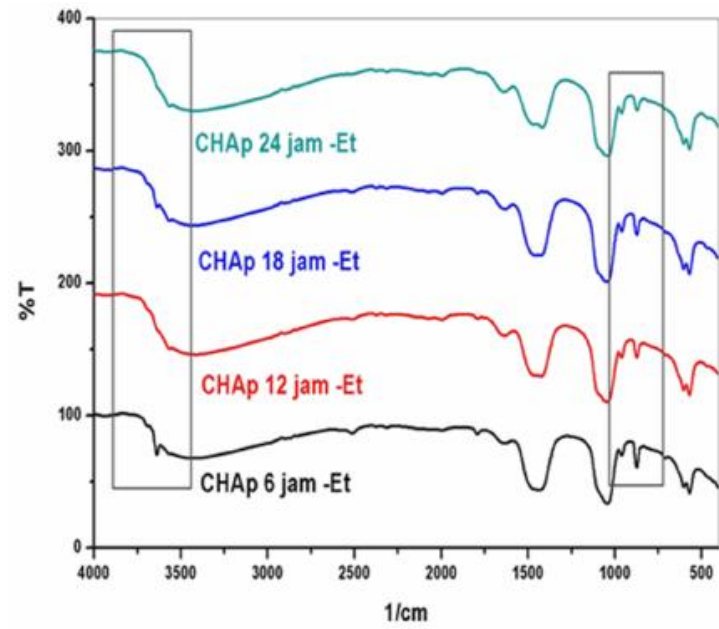

Gambar 4. Spektrum FTIR CHAp dari Goniopora cuci etanol dengan waktu sonikasi 6 jam sampai dengan 24 jam

Intensitas spektrum $\mathrm{OH}$ di daerah 3637 $\mathrm{cm}^{-1}$ pada waktu sonikasi 6 jam terlihat cukup tajam, namun seiring bertambahnya waktu sonikasi intensitasnya menjadi berkurang. Begitu pula halnya dengan intensitas spektrum karbonat di daerah $873 \mathrm{~cm}^{-1}$ yang semakin kecil pada waktu sonikasi 24 jam. Terlihat bahwa dengan pencucian etanol, substansi organik dari goniopora tanur hilang, sehingga proses konversi goniopora menjadi lebih baik.

\section{Karakterisasi Coralline Hydroxyapatite dengan X-Ray Diffraction (XRD)}

Pola difraksi sinar-X dari goniopora, $\mathrm{CHAp}$ dengan waktu sonikasi 6 jam dan 24 jam, ditampilkan pada Gambar 5. Pola difraksi sinar$X$ dari Goniopora sp. memperlihatkan kesamaan dengan pola $X R D$ aragonit pada puncak (111) di posisi $26^{\circ}$ dan (221) di posisi $52^{\circ}$. 


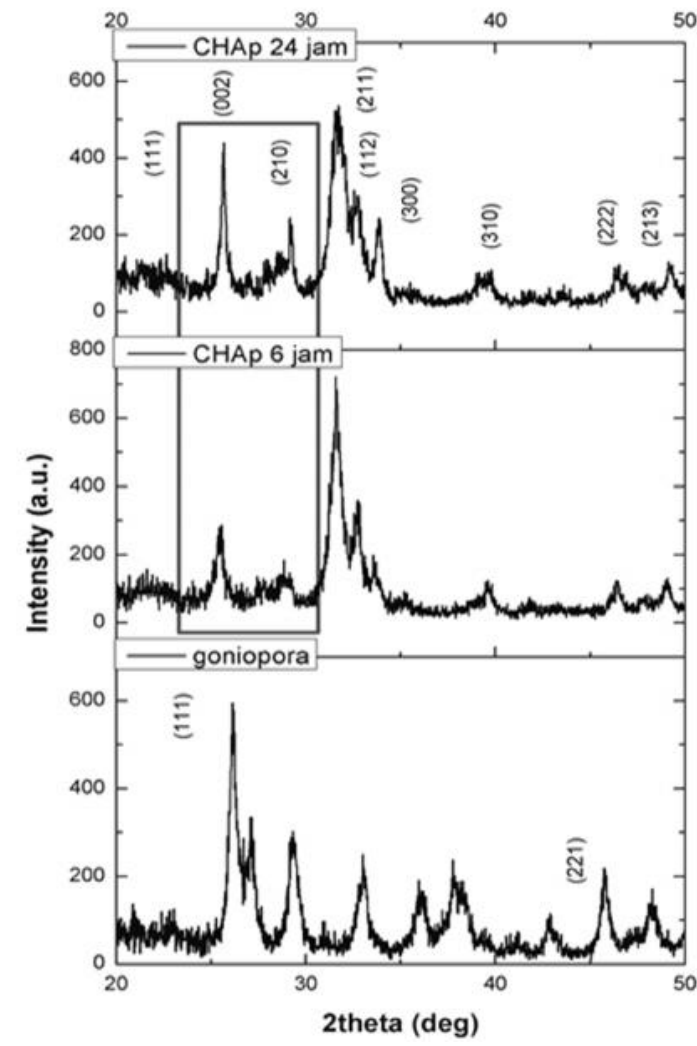

Gambar 5. Pola difraksi sinar-X dari Goniopora dan CHAp dengan waktu sonikasi 6 dan 24 jam

Selain itu terdapat pula pola $X R D$ pada posisi $34^{\circ}, 36^{\circ}$ sampai dengan $38^{\circ}$, dan $46^{\circ}$ sampai dengan $48^{\circ}$. Perubahan pola $X R D$ pada CHAp 6 jam dan CHAp 24 jam mengindikasikan terbentuknya fase baru sebagai hasil dari proses konversi melalui sonikasi. Setelah proses konversi, terbentuk pola khas dari CHAp pada posisi $26^{\circ}, 29^{\circ}, 32^{\circ}$ sampai dengan $34^{\circ}, 40^{\circ}$, dan $46^{\circ}$ sampai dengan $54^{\circ}$ (Sivakumar et al. 1996; Liu, W; Wang, T; Shen, Y; Pan, H; Peng, S; Lu 2013; Murugan and Ramakrishna 2004). Variasi waktu sonikasi berpengaruh pada intensitas puncak yang dihasilkan. Terlihat bahwa pola $X R D$ pada puncak (002) dan (210) di posisi $26^{\circ}$ sampai dengan $29^{\circ}$, antara waktu sonikasi 6 jam dan 24 jam memiliki perbedaan intensitas. $C H A p$ dengan waktu sonikasi 24 jam memiliki intensitas puncak yang lebih tinggi daripada CHAp 6 jam yang mengindikasikan bahwa semakin lama waktu sonikasi, derajat kristalinitas CHAp semakin bertambah. Hal tersebut dikonfirmasi dengan menghitung derajat kristalinitas CHAp menggunakan persamaan yang dikerjakan oleh (Sallam et al. 2012) yaitu :

$$
X c=1-\frac{\left[V_{112} / I_{300}\right]}{I 300}
$$

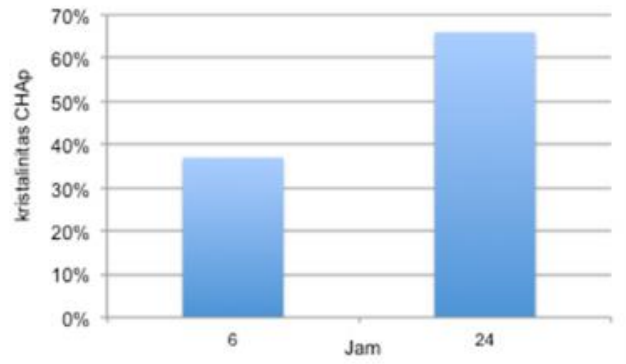

Gambar 6. Grafik perubahan kristalinitas terhadap waktu sonikasi

dimana Xc adalah derajat kristalinitas, $I_{300}$ adalah intensitas pada puncak difraksi (300), dan $V_{112 / 300}$ adalah intensitas pada lembah antara puncak difraksi (112) dan (300). Dari persamaan tersebut diperoleh perbandingan nilai derajat kristalinitas yang disajikan pada Gambar 6.

Dari grafik pada Gambar 6 terlihat bahwa semakin lama waktu sonikasi yang dilakukan dalam proses konversi, semakin besar derajat kristalinitas CHAp yang dihasilkan. CHAp dengan kristalinitas rendah berada dalam fase amorf yang relatif lebih mudah larut daripada CHAp dengan kristalinitas tinggi. Hal tersebut memiliki kekurangan yaitu dapat menyebabkan proses disintegrasi terjadi lebih cepat dan reabsorpsi jika HAp dijadikan implan (Assis et al. 2005).

\section{Analisis Rasio Kalsium dan Fosfor $(\mathrm{Ca} / \mathrm{P})$ dari Coralline Hydroxyapatite}

Kadar kalsium dari Goniopora sp. dan CHAp diukur dengan metode titrimetri. Kadar kalsium Goniopora sebelum ditanur adalah 35\% dan setelah proses tanur $900{ }^{\circ} \mathrm{C}$ dan dicuci dengan etanol berturut-turut adalah $51 \%$ dan $53 \%$. Proses tanur menyebabkan hilangnya unsur organik dari koral, sehingga setelah ditanur, dengan metode penetapan yang sama, kadar kalsium semakin meningkat. Setelah proses konversi dengan larutan diammonium hidrogen fosfat, kadar kalsium dari $C H A p$ yang terbentuk semakin berkurang. Kalsium pada $\mathrm{CaCO}_{3}$ penyusun koral berubah menjadi kalsium Fosfor dari CHAp 6 jam sampai dengan 24 jam berada pada kisaran $15 \%$ sampai dengan $22 \%$, sedangkan kadar fosfor dari CHAp-etanol berkisar $17 \%$ sampai dengan 26\%. CHAp termasuk biomaterial dalam grup kalsium fosfat dengan nilai rasio $\mathrm{Ca} / \mathrm{P}$ berada pada kisaran 0,5-2. Rasio $\mathrm{Ca} / \mathrm{P}$ dihitung dengan melakukan perbandingan antara kadar kalsium dan fosfor yang telah didapatkan.

Grafik Ca/P dari Goniopora dan CHAp disajikan pada Gambar 7. Dari grafik rasio $\mathrm{Ca} / \mathrm{P}$ terlihat bahwa nilai $\mathrm{Ca} / \mathrm{P}$ dari sampel CHAp bervariasi sesuai dengan waktu sonikasi. 


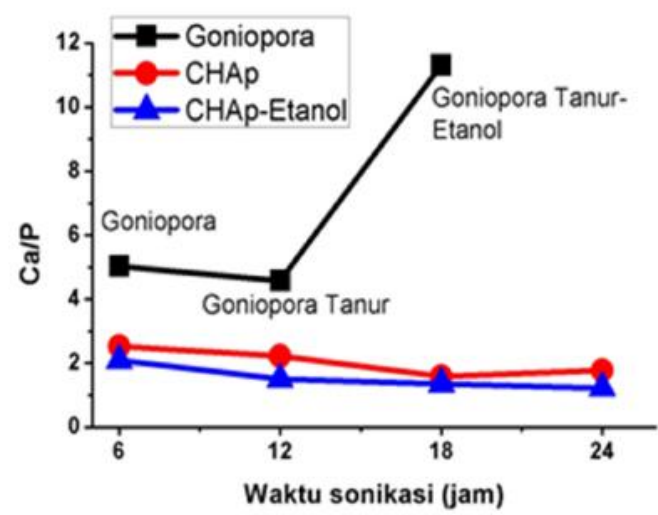

Gambar 7. Grafik rasio $\mathrm{Ca} / \mathrm{P}$ dari Goniopora dan CHAp

Nilai $\mathrm{Ca} / \mathrm{P}$ dari sampel $\mathrm{CHAp}$ berkisar antara 1,5-2,5 lebih tinggi nilainya daripada rasio $\mathrm{Ca} / \mathrm{P}$ untuk sampel CHAp dari goniopora tanur yang dicuci dengan etanol.

Hidroksiapatit yang diproses dari sumber sintetik secara stoikiometri, memiliki nilai rasio $\mathrm{Ca} / \mathrm{P}$ sebesar 1,67 . Tetapi hidroksiapatit yang berasal dari sumber biologi seperti halnya koral yang diproses secara non stoikiometri, memiliki nilai $\mathrm{Ca} / \mathrm{P}$ yang tidak tepat 1,67 .

Hal tersebut disebabkan karena pada sumber biologi juga terdapat unsur trace elemen/ion selain unsur $\mathrm{Ca}$ dan $\mathrm{P}$ yang potensial sebagai material pengganti tulang (Akram et al. 2014). Rasio $\mathrm{Ca} / \mathrm{P}$ pada sampel CHAp dengan waktu sonikasi 24 jam dihasilkan sebesar 1,7. Nilai tersebut mendekati rasio $\mathrm{Ca} / \mathrm{P}$ dari hidroksiapatit stoikiometri.

\section{Morfologi Coralline Hydroxyapatite dengan Scanning Electron Microscope Energy Dispersive X-Ray Spectroscopy (SEM-EDX) \\ Morfologi dari sampel CHAp disajikan} pada Gambar 8. Gambar 8 (a) adalah sampel CHAp hasil sonikasi 24 jam dengan perbesaran 500 kali. Bentuk dan sebaran serbuk CHAp tersebut heterogen dan cenderung terjadi aglomerasi. Hal tersebut sejalan dengan hasil penelitian yang dilakukan oleh (Jamarun et al. 2015).

Gambar 8 (b) adalah sampel CHAp dengan perbesaran 25.000 kali. Dari gambar terlihat morfologi CHAp berbentuk serpihan/flakes irregular (tidak rata) dan heterogen dengan ukuran berkisar antara 0,06 $\mu \mathrm{m}$ sampai dengan 0,67 $\mu \mathrm{m}$. Bentuk flakes irregular biasanya dihasilkan dari sintesis hidroksiapatit dengan metode hidrotermal dan sonokimia (Sadat-Shojai et al. 2013).

Spektrum Energy Dispersive X-Ray Spectroscopy (EDX) dari sampel CHAp 24 jam disajikan pada Gambar 9.
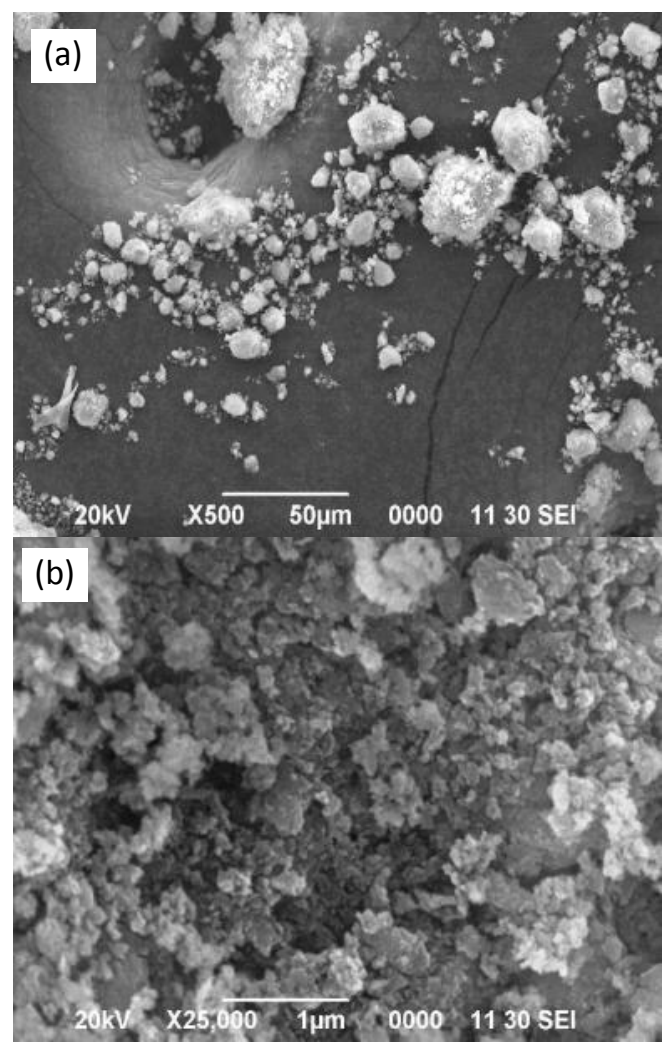

Gambar 8. Foto SEM sampel CHAp 24 jam dengan perbesaran (a) 500 kali dan (b) 25.000 kali

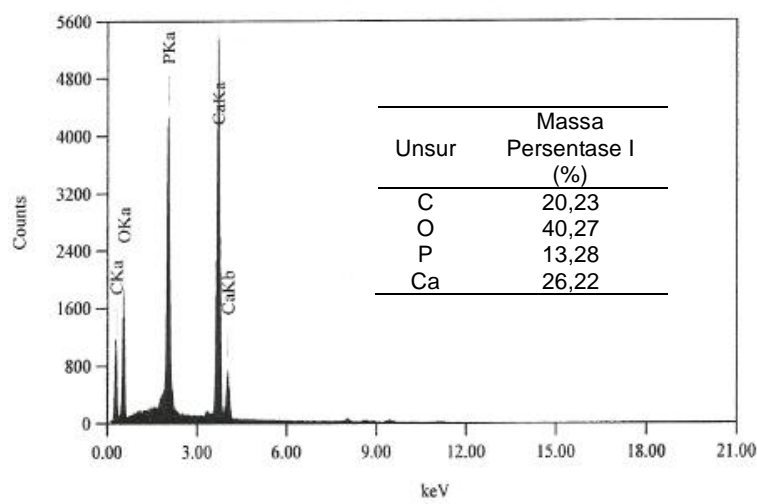

Gambar 9. Spektrum EDX sampel CHAp 24 jam

Unsur utama penyusun CHAp seperti kalsium, fosfor, karbon, dan oksigen dapat teramati melalui spektrum EDX.Terlihat bahwa unsur $\mathrm{C}, \mathrm{O}, \mathrm{P}$, dan $\mathrm{Ca}$ berturut-turut memiliki persentase massa 20,23\%; 40,27\%; 13,28\%; dan $26,22 \%$. Unsur karbon (C) dan oksigen (O) yang teramati pada sampel, berhubungan dengan adanya unsur karbonat seperti halnya yang telah dianalisis pada spektrum FTIR. 


\section{KESIMPULAN}

Konversi koral Goniopora sp. menjadi coralline hydroxyapatite (CHAp) dapat dilakukan dengan metode sonikasi. Perubahan fase pada pola difraksi sinar-X menunjukkan terbentuknya CHAp dengan puncak yang khas milik hidroksiapatit pada puncak (211), (112), dan (300) dengan derajat kristalinitas terbesar pada waktu sonikasi 24 jam yaitu 66\%. Dari spektrum FTIR dan EDX terlihat bahwa hidroksiapatit yang terbentuk adalah carbonated hydroxyapatite tipe- $\mathrm{B}$, dimana $\mathrm{CO}_{3}{ }^{2-}$ mensubtitusi $\mathrm{PO}_{4}{ }^{3-}$, dengan rasio $\mathrm{Ca} / \mathrm{P}$ sebesar 1,7 .

\section{UCAPAN TERIMA KASIH}

Ucapan terima kasih disampaikan kepada rekan-rekan di Pusat Penelitian Oseanografi LIPI yang telah membantu penulis untuk memperoleh koral Goniopora sp. sebagai bahan baku. Ucapan terima kasih juga ditujukan kepada rekan-rekan di PSTBM-BATAN yang telah membantu pengujian pola difraksi sinar $\mathrm{X}$.

\section{DAFTAR PUSTAKA}

Akram, M., R. Ahmed, I. Shakir, W. A. W. Ibrahim, and R. Hussain. 2014. "Extracting Hydroxyapatite and Its Precursors from Natural Resources." Journal of Materials Science 49 (4): 1461-75. doi:10.1007/s10853-013-7864-x.

Assis, C. M. D., L. Cristina, D. O. Vercik, M. Luís, M. Vinícius, L. Fook, and A. C. Guastaldi. 2005. "Comparison of Crystallinity between Natural Hydroxyapatite and Synthetic Cp-Ti / HA Coatings" 8 (2): 207-11.

Christopher, I., R. Dennison, V. Ca, P. M. Wild, V. Ca, D. R. Wilson, V. Ca, and P. A. Cripton. 2012. "(12) Ulllted States Patent:Coral Purification Method and Coral Thus Obtained" 2 (12): 3-8. doi:10.1197/jamia.M1139.Adar.

Clarke, S. A., P. Walsh, C. A. Maggs, and F. Buchanan. 2011. "Designs from the Deep: Marine Organisms for Bone Tissue Engineering." Biotechnology Advances 29 (6). Elsevier Inc.: 610-17. doi:10.1016/j.biotechadv.2011.04.003.

Correlo, V. M., J. M. Oliveira, J. F. Mano, N. M. Neves, and R. L. Reis. 2011. Natural Origin Materials for Bone Tissue Engineering - Properties, Processing, and Performance. Principles of Regenerative Medicine. Second Edi. Elsevier Inc. doi:10.1016/B978-0-12-381422-7.10032-X.

Dinopoulos, H., R. Dimitriou, and P. V. Giannoudis. 2012. "Bone Graft Substitutes: What Are the Options?" The Surgeon 10 (4). Elsevier: 230-39. doi:10.1016/j.surge.2012.04.001.

Gopi, D., M. T. Ansari, E. Shinyjoy, and L. Kavitha. 2012. "Synthesis and Spectroscopic Characterization of Magnetic Hydroxyapatite Nanocomposite Using Ultrasonic Irradiation." Spectrochimica Acta - Part A: Molecular and Biomolecular Spectroscopy 87. Elsevier B.V.: 245-50. doi:10.1016/j.saa.2011.11.047.

Han, Y., S. Li, X. Wang, I. Bauer, and M. Yin. 2007. "Sonochemical Preparation of Hydroxyapatite Nanoparticles Stabilized by Glycosaminoglycans." Ultrasonics Sonochemistry $14 \quad$ (3): 286-90. doi:10.1016/j.ultsonch.2006.06.002.

Hazar Yoruç, A. B., and Y. Ipek. 2012. "Sonochemical Synthesis of Hydroxyapatite Nanoparticles with Different Precursor Reagents." Acta Physica Polonica A 121 (1): 230-32.

Jamarun, N., A. Asril, Z. Azharman, T. P. Sari, and W. Sumatera. 2015. "Research Article Effect of Hydrothermal Temperature on Synthesize of Hydroxyapatite from Limestone through Hydrothermal Method" $7(6)$ : 832-37.

Kee, C. C., H. Ismail, and A. F. Mohd Noor. 2013. "Effect of Synthesis Technique and Carbonate Content on the Crystallinity and Morphology of Carbonated Hydroxyapatite." Journal of Materials Science and Technology 29 (8): 761-64. doi:10.1016/j.jmst.2013.05.016.

Liu, W., T. Wang, Y. Shen, H. Pan, S. Peng, and W.W. Lu. 2013. "Strontium Incorporated Coralline Hydroxyapatite for Engineering Bone." ISRN Biomaterials 2013: 1-11.

Murugan, R., and S. Ramakrishna. 2004. "Coupling of Therapeutic Molecules onto Surface Modified Coralline Hydroxyapatite." Biomaterials 25 (15): 3073-80. doi:10.1016/j.biomaterials.2003.09.089.

Piccirillo, C., M. M. Pintado, and P. M. L. Castro. 2013. Marine Biomaterials: Characterization, Isolation and Applications. Edited by Se-Kwon Kim. Boca Raton: CRC Press.

Ren, F. Z., and Y. Leng. 2011. "Carbonated Apatite, Type-A or Type-B?" Key Engineering Materials 493-494: 293-97. doi:10.4028/www.scientific.net/KEM.493494.293.

Rouhani, P., N. Taghavinia, and S. Rouhani. 2010. "Rapid Growth of Hydroxyapatite Nanoparticles Using Ultrasonic Irradiation." Ultrasonics Sonochemistry 17 (5). Elsevier B.V.: 853-56. doi:10.1016/j.ultsonch.2010.01.010.

Sadat-Shojai, M., M. T. Khorasani, E. DinpanahKhoshdargi, and A. Jamshidi. 2013. 
"Synthesis Methods for Nanosized Hydroxyapatite with Diverse Structures." Acta Biomaterialia 9 (8). Acta Materialia Inc.: 7591-7621.

doi:10.1016/j.actbio.2013.04.012.

Sallam, S. M., K. M. Tohami, A. M. Sallam, L. Salem, and F. A. Mohamed. 2012. "Synthesis and Characterization of Hydroxyapatite Contain Chromium." Journal of Biophysical Chemistry 3 (4): 278-82. doi:10.4236/jbpc.2012.34033.

Silva, T. H., A. Alves, B. M. Ferreira, J. M. Oliveira, L. L. Reys, R. J. F. Ferreira, R. A. Sousa, S. S. Silva, J. F. Mano, and R. L. Reis. 2012. "Materials of Marine Origin: A Review on Polymers and Ceramics of Biomedical Interest." International Materials Reviews 57 (5): 276-306. doi:10.1179/1743280412Y.0000000002

Singh, M., S. Vinodh Kumar, S. A. Waghmare, and P. D. Sabale. 2016. "AragoniteVaterite-Calcite: Polymorphs of $\mathrm{CaCO} 3$ in 7th Century CE Lime Plasters of Alampur Group of Temples, India." Construction and Building Materials 112: 386-97. doi:10.1016/j.conbuildmat.2016.02.191

Sivakumar, M., T. S. Sampath Kumar, K. L. Shantha, and K. Panduranga Rao. 1996. "Development of Hydroxyapatite Derived from Indian Coral." Biomaterials 17 (17): 1709-14. doi:10.1016/01429612(96)87651-4.

Wabnitz, C., M. Taylor, E. Green, and T. Razak. 2003. "From Ocean to Aquarium: The Global Trade in Marineornamental Species." Unep-Wcmc, 65.

Xu, Y., D. Wang, L. Yang, and H. Tang. 2001. "Hydrothermal Conversion of Coral into Hydroxyapatite." Materials Characterization 47 (2): 83-87. doi:10.1016/S1044-5803(01)00154-1.

Yoo, Y. W., G. J. Park, and W. K. Lee. 2015. "Surface Modification of Coralline Scaffold for the Improvement of Biocompatibility and Bioactivity of Osteoblast." Journal of Industrial and Engineering Chemistry 33. The Korean Society of Industrial and Engineering Chemistry: 33-41. doi:10.1016/j.jiec.2015.07.022. 